\title{
Recombinant expression of Mimivirus L725 ORFan gene product
}

\author{
H. SOBHY ${ }^{1 *}$, G. GOTTHARD ${ }^{1}$, E. CHABRIËRE ${ }^{1,2}$, D. RAOULT ${ }^{1,2}$, P. COLSON ${ }^{1,2^{*}}$ \\ ${ }^{1}$ Aix-Marseille University, URMITE UM63 CNRS 7278 IRD 198 INSERM U1095, Marseille, France; ${ }^{2}$ IHU Méditerranée Infection, \\ Assistance Publique-Hôpitaux de Marseille, Centre Hospitalo-Universitaire Timone, Pôle des Maladies Infectieuses et Tropicales \\ Clinique et Biologique, Fédération de Bactériologie-Hygiène-Virologie, Marseille, France
}

Received September 5, 2016; accepted October 5, 2016

\begin{abstract}
Summary. - Mimivirus was the first discovered amoebal giant virus. The Mimivirus virions are covered by a dense layer of approximately $130 \mathrm{~nm}$-long fibers, the length and shape of which diverge from those of other viruses. Here, we aimed at expressing the L725 protein to further confirm and study its role as a fiber-associated protein. We report Escherichia coli expression of the L725 protein, which is encoded by a Mimivirus ORFan, was previously identified by proteomics in purified viral fibers and demonstrated to be a fiber-associated protein by RNA-silencing experiments. The expressed protein was recognized by anti-Mimivirus fiber or anti-Mimivirus L725 polyclonal antibodies. This study is the only expression, to our knowledge, of a product from a Mimiviral ORFan gene.
\end{abstract}

Keywords: Mimivirus; giant virus; fiber; ORFan; gene expression

\section{Introduction}

Mimivirus was the first amoebal giant virus discovered, in 2003, and it founded the family Mimiviridae, which currently encompasses dozens of members (La Scola et al., 2003; Raoult et al., 2004; Aherfi et al., 2016). These viruses have giant capsids and genomes. In addition, their genomes harbor considerable proportions of genes encoding putative proteins of unknown function and ORFans (Raoult et al., 2004; Boyer et al., 2010; Kuznetsov et al., 2010). Thus, in Mimivirus, such genes account for $54 \%$ of the gene repertoire. Moreover, among the 114 proteins detected in the virion, $57 \%$ are hypothetical and $39 \%$ are encoded by ORFans (Renesto et al., 2006).

One specific feature of Mimivirus is a dense layer of fibers, the morphology and size of which differ from those in

*Corresponding author. E-mail: philippe.colson@univ-amu.fr; phone: +33-491-324-375. "Present address: Department of Molecular Biology, Umeå University, Umeå, Sweden.

Abbreviations: FAPs = Mimivirus fiber-associated proteins; MALDI-TOF MS = matrix-assisted laser desorption/ionization time-of-flight mass spectrometry; PAGE $=$ polyacrylamide gel electrophoresis; $\operatorname{Trx}=$ thioredoxin other viruses. These fibers are $\sim 125-140 \mathrm{~nm}$ in length and $\sim 1.4 \mathrm{~nm}$ in diameter, cover the entire capsid except for one of its vertices (Xiao et al., 2009; Klose et al., 2010; Kuznetsov et al., 2010), and have been described as glycosylated and resisting protease and collagenase treatment (Xiao et al., 2009; Boyer et al., 2011). Culturing of Mimivirus 150 times in germ-free amoebas led to the emergence of a strain devoid of fibers, along with a $16 \%$ reduction of the viral genome (Boyer et al., 2011). This Mimivirus strain exhibited reduced pathogenicity for its amoebal host and resistance to infection by virophages, which suggested the role of fibers in both host and virophage infections.

Several Mimivirus proteins have been involved in the formation of these fibers, although their precise structure and composition has not been fully resolved (Boyer et al., 2011; Klose et al., 2015). The 224-amino acid-long product of ORFan gene L725 (YP_003987254) was among the three Mimivirus proteins, with R135 (a putative GMC-type oxidoreductase) and L829 (a hypothetical protein), identified in purified fibers by 2D-gel electrophoresis coupled with matrix-assisted laser desorption/ionization time-of-flight mass spectrometry (MALDI-TOF MS) (Boyer et al., 2011). We previously silenced the genes encoding these proteins using short interfering RNA, which led to reduction in size 
or deformation of the Mimivirus fibers (Sobhy et al., 2015) We therefore proposed that these proteins could be annotated as Mimivirus fiber-associated proteins (FAPs). Here, we aimed at expressing the $\mathrm{L} 725$ protein to further confirm and study its role as a fiber-associated protein. We report the expression of the L725 protein.

\section{Materials and Methods}

For protein expression, the Mimivirus L725 gene was cloned into a Gateway pETG20A expression vector (Invitrogen, USA). This vector (obtained from Renaud Vincentelli, AFMB, Marseille, France) included thioredoxin (Trx), a hexahistidine-tag and Tobacco etch virus protease, and was used to transform the Escherichia coli Rosetta strain. E. coli was then grown at $37^{\circ} \mathrm{C}$ overnight in LuriaBertani medium at a 1:20 ratio, moved to ZYP media (with $100 \mu \mathrm{g} / \mathrm{ml}$ ampicillin and $34 \mu \mathrm{g} / \mathrm{ml}$ chloramphenicol), kept at $37^{\circ} \mathrm{C}$ until an optical density corresponding to $600 \mathrm{nmol} / \mathrm{l}$ was reached, then at $17^{\circ} \mathrm{C}$ overnight. Thereafter, bacteria were centrifuged $\left(3,000 \mathrm{xg}, 4^{\circ} \mathrm{C}\right.$, $10 \mathrm{~min}$ ), re-suspended in a lysis buffer $(150 \mathrm{mmol} / \mathrm{L} \mathrm{NaCl}, 0.25 \mathrm{mg} / \mathrm{ml}$ lysozyme, $0.1 \mathrm{mmol} / \mathrm{l}$ phenylmethylsulfonyl fluoride, $10 \mu \mathrm{g} / \mathrm{ml}$ DNase I and $20 \mathrm{mmol} / \mathrm{l} \mathrm{MgSO}_{4}$ ) and stored at $-80^{\circ} \mathrm{C}$ for $\geq 1 \mathrm{~h}$. Frozen cultures were then incubated at $37^{\circ} \mathrm{C}$, and bacterial debris were removed by centrifugation $\left(12,000 \mathrm{x} \mathrm{g}, 30 \mathrm{~min}, 4^{\circ} \mathrm{C}\right)$. Lastly, protein purification was performed on a nickel-affinity column and by sizeexclusion chromatography (ÄKTA avant 25 chromatography system (GE Healthcare, USA)). The protein concentration was measured with a NanoDrop instrument (Thermo Scientific, USA).

For the polyacrylamide gel electrophoresis (PAGE), a mix consisting of $20 \mu \mathrm{l}$ of sample and $40 \mu \mathrm{l}$ of loading buffer (Laemmli solution (Bio-Rad, USA) and dithiothreitol $350 \mathrm{mmol} / \mathrm{l}$ )) was heated at $95^{\circ} \mathrm{C}$ for $5 \mathrm{~min}$, and then was loaded on a $12 \%$ sodium dodecyl sulfate (SDS) polyacrylamide gel in a protein sample buffer (10x TrisGlycine-SDS (Euromedex, France)). Then, PAGE was performed and gels were stained by Coomassie blue. For western blotting, proteins were transferred onto nitrocellulose membranes and incubated with mouse anti-Mimivirus fiber or anti-L725 polyclonal antibodies obtained as previously described (Sobhy et al., 2015), and diluted in blocking buffer (phosphate-buffered saline (PBS), 0.3\% Tween 20 and 5\% nonfat dry milk; 1:5,000 and 1:10,000 dilutions, respectively). Membranes were probed with horseradish peroxidase-conjugated goat anti-mouse secondary antibodies (Amersham, UK).

MALDI-TOF MS analysis was performed as previously described (Boyer et al., 2011). Briefly, bands were cut and conserved in 20\% ethanol, washed for $5 \mathrm{~min}$ in $\mathrm{H}_{2} \mathrm{O}$ and dissolved in acetonitrile. Then, samples were incubated with $10 \mathrm{mmol} / \mathrm{l}$ dithiothreitol for $45 \mathrm{~min}$ at $56^{\circ} \mathrm{C}$, then with $55 \mathrm{mmol} / \mathrm{l}$ iodoacetamide and incubated for $45 \mathrm{~min}$ in the dark. The samples were washed by $\mathrm{H}_{2} \mathrm{O}$ and acetonitrile, and centrifuged for $30 \mathrm{~min}$ to remove excess $\mathrm{H}_{2} \mathrm{O}$. The proteins were digested by trypsin (12 ng/pl; Promega, USA) and incubated for $45 \mathrm{~min}$ at $4^{\circ} \mathrm{C}$, then for $2-3 \mathrm{~h}$ at $37^{\circ} \mathrm{C}$. Peptides were re-suspended in alpha-cyano-4-hydroxycinnamic acid matrix solution and spotted on the MALDI-TOF target. Analyses were performed on an Ultraflex spectrometer (Bruker Daltonics, France), and proteins were identified using the Mascot software (http://www.matrixscience.com).

For transmission electron microscopy, samples were fixed by glutaraldehyde and cacodylate buffer and deposited on 400-mesh nickel grids coated with formvar/carbon (Electron Microscopy Sciences, PA, USA). Grids were immersed in $\mathrm{NH}_{4} \mathrm{Cl}(50 \mathrm{mmol} / \mathrm{l})$, washed in PBS three times for $5 \mathrm{~min}$, then immersed twice for $10 \mathrm{~min}$ in blocking buffer (1\% normal goat serum, $1 \%$ bovine serum albumin (BSA), and $0.2 \%$ Tween 20 diluted in PBS). Thereafter, grids were incubated with anti-fiber polyclonal antibody diluted 1:100 in blocking buffer overnight at $4^{\circ} \mathrm{C}$. After four 10-min washes, grids were incubated for 90 min in biotin (Beckman Coulter, USA), diluted 1:100 in blocking buffer, then washed with $0.1 \%$ BSA-PBS $(4 \times 5 \mathrm{~min}$ ) and $0.01 \%$ cold water fish skin (CWFS) gelatin-PBS (3x10 min), incubated for 90 min with streptavidin labeled by 10 -nm gold nano-particles (Aurion, The Netherlands) diluted 1:100 in 0.01\% CWFS gelatin-PBS, then washed with PBS. After incubating with PBS-2.5\% glutaraldehyde for $15 \mathrm{~min}$, grids were washed with PBS (2x10 min) and distilled water $(10 \mathrm{~min})$. Finally, they were contrasted by uranyl acetate for $20 \mathrm{~min}$, immersed in water 60 times, and viewed with a FEI Tecnai F20 microscope operating at $200 \mathrm{keV}$.

\section{Results}

The expression of Mimivirus recombinant-L725 protein fused with Trx was achieved in the Escherichia coli Rosetta strain, as shown by SDS-PAGE as a faint band compatible with the estimated molecular mass of L725-Trx (42 kDa) (Fig. 1a). By western blotting, after incubation of expressed protein with mouse anti-L725-Trx antibodies, a band was observed at the expected molecular mass of L725-Trx (Fig. 1b). In addition, after incubation with mouse anti-Mimivirus fiber antibodies, which were verified to bind to the Mimivirus virion layer using electron microscopy and immunogold labeling (Fig. 1d), a band was observed at the expected molecular mass of L725-Trx (Fig. 1c). The L725 gene product fused with Trx and hexahistidine-tag (L725-Trx) was found to have a concentration of $0.5 \mathrm{mg} / \mathrm{ml}$ as determined with a NanoDrop spectrophotometer (Thermo Scientific). Moreover, L725 protein expression was confirmed by MALDI-TOF MS (Supplementary Fig. S1). Taken together, these results suggest that L725 gene product was obtained and L725 is a Mimivirus fiber-associated protein.

\section{Discussion}

We provide evidence that the L725 gene product, encoded by a Mimivirus ORFan, previously re-annotated as encoding a Mimivirus FAP (Sobhy et al., 2015), was obtained fused to thioredoxin in E. coli and recognized by both anti-L725 and 
(a)

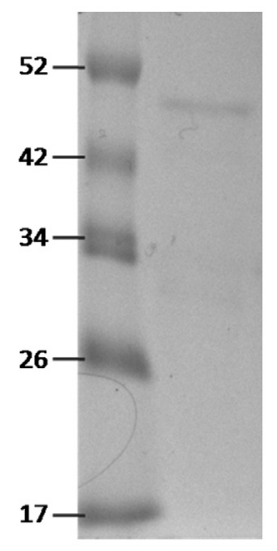

(b)

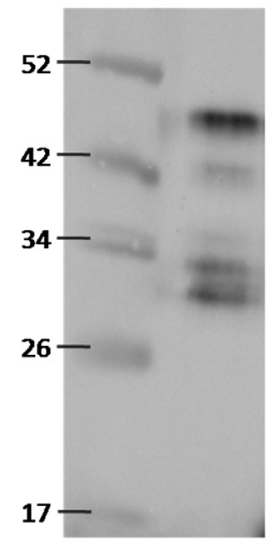

(c)

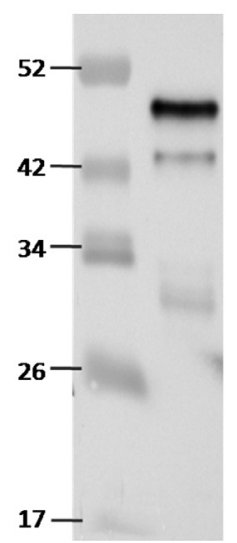

(d)

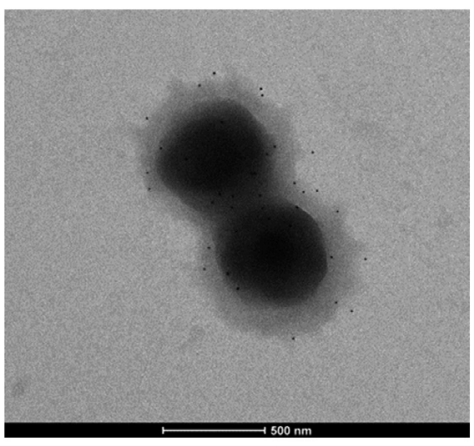

Fig. 1

Polyacrylamide gel electrophoresis (PAGE) and western blot analyses of the expressed L725 gene product

(a) SDS PAGE of the expressed L725 protein fused with thioredoxin (Trx); (b) Western blotting of the expressed L725 Mimivirus proteins fused with Trx following incubation with anti-L725 antibodies; (c) Western blotting of the expressed L725 protein fused with Trx following incubation with anti-Mimivirus fiber antibodies. (d) Transmission electron microscopy with immunogold labeling of the Mimivirus virions using anti-Mimivirus fiber polyclonal antibody. Mouse anti-L725 antibodies were obtained using L725 protein fused with Trx and used at 1:10,000 dilution; anti-Mimivirus fiber antibodies were used at 1:5,000 dilution. Expected molecular masses are as follows: L725 protein: $27 \mathrm{kDa}$; Trx: $15 \mathrm{kDa}$; 725 protein fused with Trx: $42 \mathrm{kDa}$.

anti-Mimivirus fiber antibodies. These results are congruent with previous reports indicating that the Mimivirus L725 gene product, together with three other proteins (R135, L856 and L829), is the component of the Mimivirus fibers (Boyer et al., 2011; Klose et al., 2015; Sobhy et al., 2015). The present study is one of the few studies that expressed a Mimiviral gene (Abergel et al., 2005,2007) and the only one, to our knowledge, that expressed a Mimiviral ORFan. The same method can be used to determine the function of viral structural or nonstructural proteins.

To date, Acanthamoeba spp. are the only known hosts for mimiviruses, but macrophages and peripheral blood mono- nuclear cells were shown to allow Mimivirus replication (Ghigo et al., 2008; Raoult et al., 2007; Pagnier et al., 2013; Silva et al., 2013). The determinants of Mimiviral tropism remain unknown, but the role of the fibers in host infection and virion stability is suspected (Boyer et al., 2011; Boratto et al., 2013; Dornas et al., 2014; Klose et al., 2015). The recent isolation of mimiviruses from humans presenting pneumonia (Saadi et al., 2013a,b) and the detection of sequences best matching mimivirus genomes in the metagenomes generated from various human samples (Colson et al., 2013; Rampelli et al., 2016) are incentive to decipher the mechanisms of entry of these giant viruses into eukaryotic cells. With this in mind, further analyses should specify the structure of the Mimivirus fiber and protein interactions that allow fiber biosynthesis in mimiviruses.

Acknowledgements. We are grateful to Renaud Vincentelli (AFMB, Marseille, France) for providing the expression vector, and to Said Azza, Claude Nappez and Jean-Pierre Baudoin for technical assistance. Haitham Sobhy received a grant from the Infectiopole Sud Foundation.

Supplementary information is available in the online version of the paper.

\section{References}

Abergel C, Chenivesse S, Byrne D, Suhre K, Arondel V, Claverie JM (2005): Mimivirus TyrRS: preliminary structural and functional characterization of the first amino-acyl tRNA synthetase found in a virus. Acta Crystallogr. Sect. F. Struct. Biol. Cryst. Commun. 61, 212-215. https://doi. org/10.1107/S174430910500062X

Abergel C, Rudinger-Thirion J, Giege R, Claverie JM (2007): Virusencoded aminoacyl-tRNA synthetases: structural and functional characterization of mimivirus TyrRS and MetRS. J. Virol.81, 12406-12417. https://doi.org/10.1128/JVI.01107-07

Aherfi S, Colson P, La Scola B, Raoult D (2016): Giant Viruses of Amoebas: An Update. Front. Microbiol. 7, 349. https:// doi.org/10.3389/fmicb.2016.00349

Boratto PV, Dornas FP, Andrade KR, Rodrigues R, Peixoto F, Silva LC, La Scola B, Costa AO, de Almeida GM, Kroon EG, Abrahao JS (2014): Amoebas as mimivirus bunkers: increased resistance to UV light, heat and chemical biocides when viruses are carried by amoeba hosts. Arch. Virol. 159, 1039-1043.

Boyer M, Azza S, Barrassi L, Klose T, Campocasso A, Pagnier I, Fournous G, Borg A, Robert C, Zhang X, Desnues C, Henrissat B, Rossmann MG, La Scola B, Raoult D (2011): Mimivirus shows dramatic genome reduction after intraamoebal culture. Proc. Natl. Acad. Sci. USA 108, 10296-10301. https://doi.org/10.1073/pnas.1101118108

Boyer M, Gimenez G, Suzan-Monti M, Raoult D (2010): Classification and determination of possible origins of ORFans through analysis of nucleocytoplasmic large 
DNA viruses. Intervirology 53, 310-320. https://doi. org $/ 10.1159 / 000312916$

Colson P, Fancello L, Gimenez G, Armougom F, Desnues C, Fournous G, Yoosuf N, Million M, La Scola B, Raoult D (2013): Evidence of the megavirome in humans. J. Clin. Virol. 57, 191-200. https://doi.org/10.1016/j.jcv.2013.03.018

Dornas FP, Silva LC, de Almeida GM, Campos RK, Boratto PV, Franco-Luiz APM, La Scola B, Ferreira PCP, Kroon EG, Abrahão JS (2014): Acanthamoeba polyphaga mimivirus stability in environmental and clinical substrates: implications for virus detection and isolation. PLoS One. 9, e87811. https://doi.org/10.1371/journal.pone.0087811

Ghigo E, Kartenbeck J, Lien P, Pelkmans L, Capo C, Mege JL, Raoult D (2008): Ameobal pathogen mimivirus infects macrophages through phagocytosis. PLoS Pathog. 4, e1000087. https://doi.org/10.1371/journal. ppat. 1000087

Klose T, Herbst DA, Zhu H, Max JP, Kenttamaa HI, . Rossmann MG (2015): A Mimivirus Enzyme that Participates in Viral Entry. Structure 23, 1058-1065. https://doi.org/10.1016/j. $\underline{\text { str.2015.03.023 }}$

Klose T, Kuznetsov YG, Xiao C, Sun S, McPherson A, Rossmann MG (2010): The three-dimensional structure of Mimivirus. Intervirology 53, 268-273. https://doi.org/10.1159/000312911

Kuznetsov YG, Xiao C, Sun S, Raoult D, Rossmann M, McPherson A (2010): Atomic force microscopy investigation of the giant mimivirus. Virology 404, 127-137. https://doi. org/10.1016/j.virol.2010.05.007

La Scola B, Audic S, Robert C, Jungang L, de L X, Drancourt M, Birtles R, Claverie JM, Raoult D (2003): A giant virus in amoebae. Science 299, 2033. https://doi.org/10.1126/ science. 1081867

Pagnier I, Reteno DG, Saadi H, Boughalmi M, Gaia M, Slimani M, Ngounga T, Bekliz M, Colson P, Raoult D, La SB (2013): A decade of improvements in Mimiviridae and Marseilleviridae isolation from amoeba. Intervirology 56, 354-363. https://doi.org/10.1159/000354556

Rampelli S, Soverini M, Turroni S, Quercia S, Biagi E, Brigidi P, Candela M (2016): ViromeScan: a new tool for metagenomic viral community profiling. BMC Genomics. 17, 165-2446. https://doi.org/10.1186/s12864-016-2446-3

Raoult D, Audic S, Robert C, Abergel C, Renesto P, Ogata H, La Scola B, Suzan M, Claverie JM (2004): The 1.2-megabase genome sequence of Mimivirus. Science 306, 1344-1350. https://doi.org/10.1126/science.1101485

Raoult D, La Scola B, Birtles R (2007): The discovery and characterization of Mimivirus, the largest known virus and putative pneumonia agent. Clin. Infect. Dis. 45, 95-102. https://doi.org/10.1086/518608

Renesto P, Abergel C, Decloquement P, Moinier D, Azza S, Ogata H, Fourquet P, Gorvel JP, Claverie JM (2006): Mimivirus giant particles incorporate a large fraction of anonymous and unique gene products. J. Virol. 80, 11678-11685. https://doi.org/10.1128/JVI.00940-06

Saadi H, Pagnier I, Colson P, Cherif JK, Beji M, Boughalmi M, Azza S, Armstrong N, Robert C, Fournous G, La Scola B, Raoult D (2013a): First isolation of Mimivirus in a patient with pneumonia. Clin. Infect. Dis. 57, e127-e134. https://doi. org $/ 10.1093 / \mathrm{cid} / \mathrm{cit} 354$

Saadi H, Reteno DG, Colson P, Aherfi S, Minodier P, Pagnier I, Raoult D, La Scola B (2013b): Shan virus: a new mimivirus isolated from the stool of a Tunisian patient with pneumonia. Intervirology 56, 424-429. https://doi. org/10.1159/000354564

Silva LC, Almeida GM, Oliveira DB, Dornas FP, Campos RK, La Scola B, Ferreira PC, Kroon EG, Abrahao JS (2013): A resourceful giant: APMV is able to interfere with the human type I Interferon system. Microbes. Infect. 16, 187-195. https://doi.org/10.1016/j.micinf.2013.11.011

Sobhy H, La Scola B, Pagnier I, Raoult D, Colson P (2015): Identification of giant Mimivirus protein functions using RNA interference. Front. Microbiol. 6, 345. https://doi. org $/ 10.3389 /$ fmicb.2015.00345

Xiao C, Kuznetsov YG, Sun S, Hafenstein SL, Kostyuchenko VA, Chipman PR, Suzan-Monti M, Raoult D, McPherson A, Rossmann MG (2009): Structural studies of the giant mimivirus. PLoS Biol. 7, e92. https://doi.org/10.1371/ journal.pbio.1000092 